\title{
Vaktaalrubriek
}

\section{Die stand van woordeboeke in die natuurwetenskappe}

\author{
A. Coetser \\ Suid-Afrikaanse Akademie vir Wetenskap en Kuns
}

Van die ongeveer honderd-en-vier tweetalige en verklarende vakwoordeboeke wat in Afrikaans beskikbaar is, is nagenoeg sewe-en-vyftig uitsluitlik gerig op die natuurwetenskappe. Hieronder tel byvoorbeeld die volgende:

Biologiewoordeboek, Geneeskundige Woordeboek, Genetiese en Statistiese Woordeboek vir Veekunde, Geologiese en Verwante Terme, Geomorfologiese Woordelys, Insekname, Grondkundelys, Wiskundewoordeboek, Weerkunde- en Hidrologiewoordeboek, Kernenergieterme, Aptekerswoordeboek, Plantname, Rekenaarwoordeboek, Statistiekwoordeboek, Dierkundewoordeboek en die Veeartsenykundige Woordeboek.

Een-en-twintig natuurwetenskapvakwoordeboeke is verklarend en ses-en-dertig is in een of ander vorm tweetalig: Afrikaans-Engels, Engels-Afrikaans; Engels-Afrikaans; Afrikaans-Engels, Engels-Afrikaans, verklarend; Engels-Afrikaans, verklarend; verklarend in Afrikaans en Engels; Engels-Wetenskaplike naam - Afrikaans, Afrikaans-Wetenskaplike naam - Engels, Wetenskaplike naam - EngelsAfrikaans; en Engels-Afrikaans met Franse, Duitse en Nederlandse indekse.

Die meeste van die vakwoordelyste in die natuurwetenskappe is saamgestel deur die volgende instansies: Suid-Afrikaanse Buro vir Standaarde; Departement Nasionale Opvoeding se Diensburo; Suid-Afrikaanse Akademie vir Wetenskap en Kuns; Taaldienste van die Poskantoor en Suid-Afrikaanse Vervoerdienste en die Nasionale Vakterminologiediens. Organisasies soos YSKOR, SASOL en die WNNR was betrokke by indiwiduele publikasies. Sowat $6 \%$ van die gepubliseerde vakwoordeboeke in die natuurwetenskappe is op eie inisiatief deur privaat outeurs geskryf en via uitgewers uitgegee.

Lopende vakwoordeboekprojekte wat deur die $\mathrm{Na}$ sionale Vakterminologiediens behartig word, sluit in die -

Geologiewoordeboek: Die reeds versamelde 23000 terme is in die loop van 1986/1987 grootliks aangevul uit 'n paar subgebiede van die geologie, waaronder (om maar enkeles te noem) sedimentologie, stratigrafie, gletserkunde, kristallografie en geochronologie sorteer.

Rekenaarwoordeboek: Met die oog op die snelle ontwikkelingstempo op hierdie gebied van die tegnologie word terminologie uit die jongste bronne aangevul.

Biologiese Wetenskappe: Die terminologie van die volgende vakgebiede word nog steeds bygewerk met die oog op die nuutste ontwikkelinge op die gebied van die entomologie (aragnologie ingesluit), mikrobiologie en ekologie. Die Tuinbouwoordeboek word tans finaal geproeflees en vir publikasie gereed gemaak.

Meganiese Ingenieurswese: Die samestelling van hierdie boek is reeds ver gevorder. Die aangestelde terminologiekomitees is tans besig om bykomende terme uit verskillende handboeke te ekserpeer.

Verskeie woordeboeke wat met die loop van jare onder die beskerming van die Suid-Afrikaanse Akademie die lig gesien het, geniet tans hersiening. Wat die natuurwetenskappe betref, is dit veral die Wiskunde-, Chemie-, Bou- en Fisikawoordeboek wat ter sake is.

Die Wiskundewoordeboek het sy beslag reeds in 1924 gekry met die Engels-Afrikaanse Wiskundige Terme wat deur prof. W.F.C. Arndt opgestel is. Dié lys is verskeie kere aangevul en herdruk, totdat die Wiskundewoordeboek in 1971 in sy huidige vorm verskyn het. Die afgelope aantal jare het 'n hersieningskomitee onder leiding van prof. P.J. Zietsman hierdie werk hersien. Op 2 Junie 1987 het prof. Zietsman 'n eksemplaar van die hersiene uitgawe amptelik aan die Akademie oorhandig. (Moontlik pryk die nuwe Wiskundewoordeboek reeds in die boekrak van elke matematikus wanneer hierdie ar(ikel verskyn!)

In 1951 het die Chemiewoordeboek, onder die naam Lys Skeikundige Terme, vir die eerste keer verskyn. Na aanvulling het hersiene uitgawes in 1955 en 1968 onderskeidelik, verskyn. Dr. D.F. Louw van die WNNR is sedert 1978 (bykans manalleen) besig om die Chemiewoordeboek te hersien. Verwagte voltooiingsdatum: einde 1987.

Die eerste publikasie van die pasgestigte Vaktaalburo van die Suid-Afrikaanse Akademie in 1950 was die Ontwerplys Bouterme (Eng. -Afr.). In 1951, 1957, 1960 en 1965 het verbeterde uitgawes en herdrukke die lig gesien. Prof. J.T.B. Viljoen is tans die sameroeper van 'n komitee wat die Bouwoordeboek hersien - en goeie vordering word gerapporteer.

Die geskiedenis van die Fisikawoordeboek strek terug tot 1948 toe 'n Voorlopige Fisiese Woordelys opgestel is. Die woordeboek soos ons dit nou ken, is in 1977 uitgegee en het 'n goeie resensie in die South $A f$ rican Journal of Science van November 1977 geniet. 'n Komitee onder leiding van dr. C.J. Ritter vorder op die oomblik goed met die hersiening van die 1977-uitgawe; die kommentare wat op die anvullende terme ingewag is, word nou gefinaliseer. 
Die gedagte aan een omvattende natuurwetenskapwoordeboek geniet sedert 1987 die aandag van die Fakulteit Natuurwetenskap en Tegniek van die S.A. Akademie. Hoewel hierdie gedagte poog om die pro- bleem van duplisering te ondervang, kan dit dalk teen 'n ander probleem, naamlik dié van onhanteerbaarheid, stuit. Daar lê nietemin uitdagende en belofteryke moontlikhede in so 'n projek opgesluit.

\title{
Hersiening van die Sterrekundewoordeboek
}

\author{
J.H. de Klerk
}

Dept. Wiskunde en Toegepaste Wiskunde, Potchefstroomse Universiteit vir CHO, Potchefstroom 2520

In samewerking met die Nasionale Vakterminologiediens van die Departement Nasionale Opvoeding is 'n hersieningskommissie reeds vir ongeveer die afgelope twee jaar besig met die hersiening en uitbreiding van die bestaande Sterrekundewoordeboek.

Die Sterrekundewoordeboek het reeds in 1966 verskyn en is destyds saamgestel deur 'n komitee van die Vaktaalburo met prof. H.J. Terblanche as voorsitter. Vir 'n hele aantal jare is hierdie woordeboek nou al reeds uit druk. Daarbenewens is daar ook talle woorde wat nie in die woordeboek voorkom nie enersyds woorde wat toentertyd eenvoudig net onopgemerk verbygegaan het en andersyds woorde wat intussen ontstaan het. Wat laasgenoemde aanbetref, hoef 'n mens maar net te dink aan die ontwikkeling van die ruimtevaart gedurende die afgelope twee dekades en hoeveel terme uit hierdie gebied in Afrikaans opgeneem is.

In die lig van bogenoemde en ook omdat daar deesdae ' $n$ groot belangstelling in sterrekunde is, is daar gemeen dat dit noodsaaklik is om die Sterrekundewoordeboek te hersien en by te werk. Daar is ook besluit om die hele proses so veel as moontlik te rekenariseer. Dit vergemaklik nie net die huidige werk aan die woordeboek nie, maar het ook tot gevolg dat dit in die toekoms makliker sal wees om die woordeboek op datum te hou.

Aandag sal in die res van dié artikel aan die volgende sake gegee word: Belangstellingsgroepe, die werkswyse van die hersieningskommissie, eie riglyne vir die saamstel van die Sterrekundewoordeboek en enkele probleme wat tot dusver ondervind is.

\section{Belangstellingsgroepe}

Onder belangstellendes resorteer mense uit 'n verskeidenheid gebiede. Anders as baie vakgebiede, het sterrekunde 'n aktiewe aanhang onder amateurs, sodat dit dus nie snaaks is om byvoorbeeld ' $n$ predikant-amateursterrekundige te kry nie. Die persone op die hersieningskommissie is om hierdie rede dus nie net akademici of beroepsterrekundiges nie, maar ook amateurs. Dis dikwels juis in die volksmond waar nuwe sterrekundige terme geskep word en nie net by universiteite of sterrewagte nie.

\section{Werkswyse van die Hersieningskommissie}

Die werkswyse wat tans gevolg word, is dat opdragte gereeld per pos aan die lede van die hersieningskommissie gestuur word. Aanvanklik is die bestaande woordeboek deurgewerk en hersien, maar na mate die taak meer en meer einde se kant toe staan, word daar meer klem gelê op die opstel en deurwerk van lyste nuwe woorde.

Aangesien die meeste werk per pos gedoen kan word, is onkostes relatief klein. Die meeste werk word ook per rekenaar gedoen, sodat die administratiewe sy van die saak nie te ingewikkeld raak nie.

\section{Eie riglyne vir die saamstel van die Woordeboek} Bo-en-behalwe die gebruiklike riglyne wat geld vir die saamstel van enige vakwoordeboek, het die hersieningskommissie vir homself ook nog die volgende verdere riglyne gestel:

Omdat 'n groot persentasie van die mense wat in sterrekunde geinteresseerd is, skoolkinders is, is gevoel dat die woordeboek ook bruikbaar moet wees vir kinders. Die volgende maatstaf word gebruik vir die opneem van 'n woord: Sal 'n skoolkind van standerd 9 moontlik hierdie woord teëkom en wil weet wat dit in Afrikaans/Engels is?

Die gevoel was verder ook - hoewel daar 'n mate van meningsverskil was - dat meer eiename (byvoorbeeld name van kraters, sterre, planetoïdes, ensovoorts) in die woordeboek opgeneem moet word. Die meeste van hierdie woorde het natuurlik in Afrikaans en Engels dieselfde vorm, sodat mens waarskynlik sou kon redeneer dat dit nie nodig is om eiename op te neem nie. Tog het heelwat mense veral miskien juis Afrikaanssprekendes - gemeen dat Afrikaanse sterrekundige boeke so $\mathrm{min}$ is, dat dit juis nodig is om die woorde ook op te neem. Daar is dus uiteindelik wel besluit op die opneem van eiename, 
maar steeds moet 'n mens jouself maan om nie letterlik elke eienaam op te neem nie.

'n Verdere riglyn wat gestel is vir die saamstel van hierdie woordeboek, is dat dit nie net 'n vertalende rol moet speel nie, maar deels ook 'n definiërende rol - met ander woorde: sommige woorde word ook effens omskryf. In die geval van eiename is hierdie definiërende funksie juis nuttig, anders sal bitter min lesers weet dat Olympia 'n planetoïde is en nie, sê maar, 'n krater op die maan nie.

\section{Enkele probleme}

Ons wil graag melding maak van 'n aantal probleme wat met die hersiening ondervind is.

Daar is reeds verwys na die opneem van eiename. Ons wil weer terugkom op hierdie saak ten opsigte van die probleme wat daarmee ondervind is. Een van die eerste probleme waarmee die hersieningskommissie te doen gekry het, was die vraag of ' $n$ bepaalde voorwerp na 'n persoon vernoem is of na een of ander fisiese aspek. Is die "Rook mountains" op die Maan byvoorbeeld vernoem na ene Rook of moet dit in Afrikaans bekend staan as Toringgebergte? Is die "Barbell nebula" in Afrikaans Barbellnewel, Dubbelbolnewel of Staafgewignewel?

'n Verdere probleem in verband met eiename is die volgende: Moet beroemde sterrekundiges se name opgeneem word (dit word nie noodwendig in Afrikaans en Engels dieselfde gespel nie)? Moet die name van vuurpyle opgeneem word? En wat van ruimtesendings? Indien ja, waar moet die streep getrek word?

Heelwat sterrekundige benamings kom uit Arabies, en hier het dit ook geblyk dat daar 'n groot variasie in spelling is, byvoorbeeld Sadalsud teenoor Sadal Suud, Unukalhay teenoor Unuk al Hay en Zuben el Chamali teenoor Zuben en Schemali en Zyben es Chamali. Die vraag wat hier ontstaan, is of alle variasies opgeneem moet word, of net een. Indien net een, watter een? 'n Volgende probleem wat vermelding verdien, is gevalle wat 'n mens "lusse"' sou kon noem. Let op na die volgende voorbeelde: Die Engelse woord "appulse" word deur die Sterrekundewoordeboek slegs vertaal met "appuls" (wat niksseggend is). Die Afrikaanse woord "appuls" word op sy beurt weer slegs vertaal met "appulse". 'n Mens is dus terug by die begin, en niks wyser nie. As 'n mens dus nie weet wat die Engels beteken nie, sal jy ook nie weet wat die Afrikaans beteken nie. Selfs Bosman, Van der Merwe en Hiemstra se nuwe Tweetalige Woordeboek kon hier nie help nie. 'n Tweede voorbeeld (wat nog bietjie erger is) is "invar" (Engels), "invar" (Afrikaans) en weer “invar"' (Engels).

Sekere woorde het oor die jare al moeilike kalante geword. Moet "galaxy" byvoorbeeld deur galaktika, galaksie of sterrestelsel vertaal word? En is die Engelse "cluster of galaxies" in Afrikaans 'n tros van sterrestelsels, 'n bondel van sterrestelsels, 'n sterrestelseltros, 'n sterrestelselbondel, 'n galaksietros, ensovoorts?

Sommige vertalings in die ou Sterrekundewoordeboek stel 'n mens net eenvoudig nie tevrede nie, en beter vertalings word gesoek. Die Engelse "epact", Afrikaans "epak" is 'n voorbeeld hiervan. Net so is die Engelse "crochet", Afrikaans "crochet" niksseggend, en in 'n sekere mate ook die Engelse "metagalactic", Afrikaans "metagalakties".

Ten spyte van hierdie probleme moet dit darem gemeld word dat die groot meerderheid woorde nie sulke moeilike gevalle is nie en betreklik min probleme bied.

Samevattend kan gemeld word dat die werk aan die hersiening van die Sterrekundewoordeboek goed verloop en dat ons tevrede is met die vordering van die afgelope twee jaar. Waar die hersieningsaspek gedurende die afgelope tyd heelwat aandag ontvang het, sal die opname aspek (wat moontlik 'n groter uitdaging is) in die volgende jaar of twee meer aandag ontvang. 